\title{
THE NUMBER OF ALVEOLI IN THE TERMINAL RESPIRATORY UNIT OF MAN DURING LATE INTRAUTERINE LIFE AND CHILDHOOD
}

\author{
BY \\ J. L. EMERY and A. MITHAL* \\ From the Department of Pathology, The Children's Hospital, Sheffield
}

(RECEIVED FOR PUBLICATION MARCH 14, 1960)

Until recently the child's lung was considered to be a miniature of the adult lung (Kölliker, 1881). Broman (1923) demonstrated that the bronchial tree underwent further branching after birth (in cows), that foetal alveolar ducts became bronchioles and that there was a postnatal increase of over $30 \%$ in the number of subpleural vesicles in the middle lobe of the right lung in rabbits and man.

Much work has been done on the minute structure of the terminal pulmonary units, of which Miller's book (Miller, 1947) is a landmark. Most of the research has been carried out on animals and no one, as far as we are aware, has worked on more than 15 children's lungs. No attempt appears to have been made to estimate postnatal alveolar growth on a quantitative basis. The present report records a statistical survey of the growth of the human terminal respiratory unit during the latter half of intrauterine life and through childhood.

\section{Material and Methods}

The lungs for study came from 2,500 necropsies carried out by the Department of Pathology at the Children's Hospital, Sheffield, during the years 1950-59. The routine necropsy practice at this hospital is to fix the lung while still attached to the heart and trachea. A block of tissue is then taken from each lobe at right angles to the direction of the main bronchus and at a distance of approximately one-third from the root of the lung to the periphery. If pathological lesions are suspected elsewhere in the lung, further blocks are taken.

The whole of the material was surveyed and the sections divided into categories indicating whether or not the lung showed gross pathology, and whether the tissues were well preserved and suitable for detailed study. The clinical histories were surveyed and all cases in which there was a congenital deformity of the heart, or a gross deformity of any other organ, were eliminated. This left approximately 600 well preserved lungs from apparently normally formed children. (Lungs showing a

\footnotetext{
* In receipt of a grant from the Medical Research Council.
}

small amount of oedema or areas of partial collapse were not eliminated provided the tissues were well preserved.)

Owing to the high mortality around birth all the lungs from older children were used and a random selection, based on necropsy number, from those dying during 36-40 weeks gestation. When the lungs were presented for histological assessment, the person examining the sections was not given details of the child's age or the cause of death.

Method of Assessment of Terminal Segment. Our concept of the terminal respiratory unit of the lung is of that mass of air spaces distal to a terminal respiratory bronchiole, the latter being a complete tube lined by epithelium. This, in Miller's (1947) classification, consists of the alveolar duct, atria and alveoli. Several methods of assessment were tried but the only one showing adequate reproducibility consisted of ignoring all the bronchioles completely lined by epithelium and noting only those lined by epithelium in one part of the wall. From the centre of such a respiratory tube, a perpendicular line was dropped on to the nearest and definite connective tissue septum (Fig. 1). This vertical line was made by using a single hair diaphragm in the eye-piece of the microscope. The number of alveoli cut by this line was then counted. This method overcomes, as far as is possible, the effects of varying degrees of collapse or of the presence of fluid or exudate in some alveoli. Ten such counts were done from each case. It is surprising how few such measurements can be taken from any one section. After all counts had been completed the means were correlated with age on a scatter diagram. The lungs from 309 children were examined in this way.

Fig. 1, showing sections from the lungs of a child of approximately 28 weeks maturity, and from a child of 11 months, illustrates the method of counting the alveoli.

\section{Results}

The final average figures in the different age groups, together with the errors of the means based upon the standard deviations and number of cases, are given in the Table and shown graphically in 

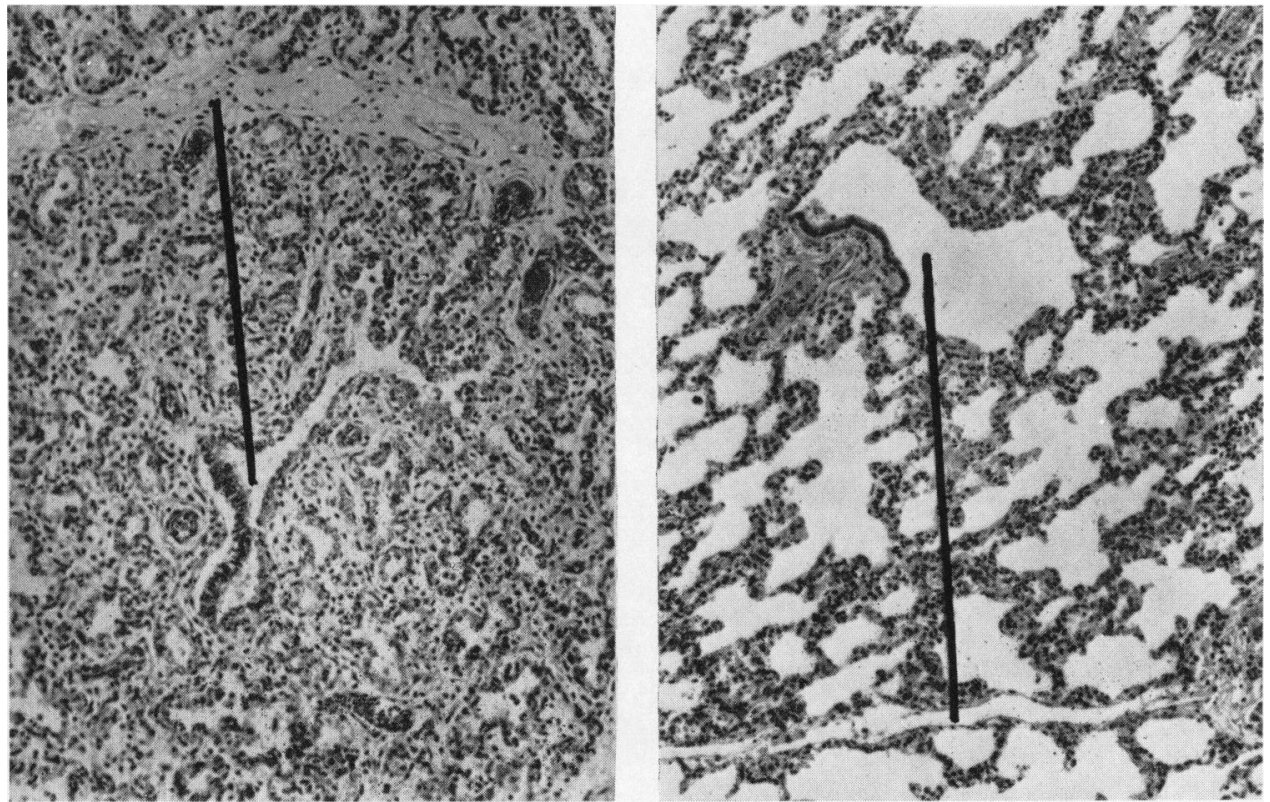

Fig. 1.-Photographs of lungs to illustrate the method of counting: one from a child of 28 weeks gestation (left) and the other from a child of 11 months (right). The black line indicates the position of the hair line as used under the microscope.

TABLE

ALVEOLAR COUNTS

\begin{tabular}{|c|c|c|c|c|c|}
\hline Age Group & $\begin{array}{l}\text { No. of } \\
\text { Cases }\end{array}$ & $\begin{array}{c}\text { Radial Alveoli } \\
\text { Count } \\
\text { (mean) }\end{array}$ & S.D. & $\begin{array}{c}\text { S.E. } \\
\text { of Mean }\end{array}$ & $\begin{array}{c}\text { Estimated Number } \\
\text { of Alveoli for } \\
\text { Terminal Lung } \\
\text { Unit }\end{array}$ \\
\hline $\begin{array}{c}\text { Gestational } \\
24-27 \text { weeks } \\
28-31 \text { weeks } \\
32-35 \text { weeks } \\
36-39 \text { weeks } \\
\text { Birth (40 weeks) } \\
1 \text { wk-41 mths } \\
5-9 \text { mths } \\
10-15 \text { mths } \\
15-22 \text { mths } \\
23-30 \text { mths } \\
2 \text { yrs } 7 \text { mths- } 3 \text { yrs } 6 \text { mths } \\
3 \text { yrs } 7 \text { mths- } 4 \text { yrs } 6 \text { mths } \\
4 \text { yrs } 7 \text { mths- } 5 \text { yrs } 6 \text { mths } \\
5 \text { yrs } 7 \text { mths- } 6 \text { yrs } 6 \text { mths } \\
6 \text { yrs } 7 \text { mths- } 7 \text { yrs } 6 \text { mths } \\
7 \text { yrs } 7 \text { mths- } 8 \text { yrs } 6 \text { mths } \\
8 \text { yrs } 7 \text { mths- } 9 \text { yrs } 6 \text { mths } \\
9 \text { yrs } 7 \text { mths-10 yrs } 6 \text { mths } \\
10 \text { yrs } 7 \text { mths-11 yrs } 6 \text { mths } \\
11 \text { yrs } 7 \text { mths-12 yrs } 6 \text { mths }\end{array}$ & $\begin{array}{r}6 \\
12 \\
10 \\
9 \\
25 \\
38 \\
25 \\
34 \\
28 \\
28 \\
25 \\
15 \\
13 \\
8 \\
9 \\
4 \\
5 \\
6 \\
4 \\
5\end{array}$ & $\begin{array}{l}2 \cdot 2 \\
2 \cdot 6 \\
3 \cdot 2 \\
3 \cdot 6 \\
4 \cdot 4 \\
5 \cdot 5 \\
6 \cdot 6 \\
7 \cdot 0 \\
7 \cdot 1 \\
7 \cdot 2 \\
7 \cdot 3 \\
7 \cdot 5 \\
7 \cdot 6 \\
7 \cdot 8 \\
8 \cdot 0 \\
8 \cdot 2 \\
8 \cdot 5 \\
8 \cdot 7 \\
9 \cdot 0 \\
9 \cdot 3\end{array}$ & $\begin{array}{l}0.60 \\
0.80 \\
0.90 \\
0.90 \\
0.90 \\
1.38 \\
1.68 \\
1.68 \\
1.75 \\
1.42 \\
1.42 \\
1.52 \\
1.12 \\
1.31 \\
1.31 \\
1.50 \\
1.70 \\
1.80 \\
1.82 \\
2.00\end{array}$ & $\begin{array}{l}0 \cdot 19 \\
0 \cdot 20 \\
0 \cdot 20 \\
0 \cdot 20 \\
0 \cdot 17 \\
0 \cdot 21 \\
0 \cdot 34 \\
0 \cdot 22 \\
0 \cdot 22 \\
0 \cdot 19 \\
0 \cdot 19 \\
0 \cdot 39 \\
0 \cdot 31 \\
0 \cdot 28 \\
0 \cdot 28 \\
0 \cdot 28 \\
0 \cdot 35 \\
0 \cdot 40 \\
0 \cdot 40 \\
0 \cdot 40\end{array}$ & $\begin{array}{r}42 \\
130 \\
340 \\
1,370 \\
1,556 \\
1,715 \\
2,200 \\
2,630 \\
3,220\end{array}$ \\
\hline
\end{tabular}

Note: Gestational age, based upon the last menstrual period, is used up to birth and postnatal age after birth.

Fig. 2. There is very great variability between children of the same age; some lungs were found from children of 2 years of age showing a similar alveolar count to that of children of 10 years. There is an increase in the alveolar count throughout the whole of childhood. The radial alveolar count goes from approximately $2 \cdot 5$ at 28 weeks of gestation to 4.4 at full term. By the age of 1 year, the alveolar count increases to nearly seven. This increase continues in an apparently uniform way throughout the whole of childhood, until it reaches between eight and nine at the period just preceding 


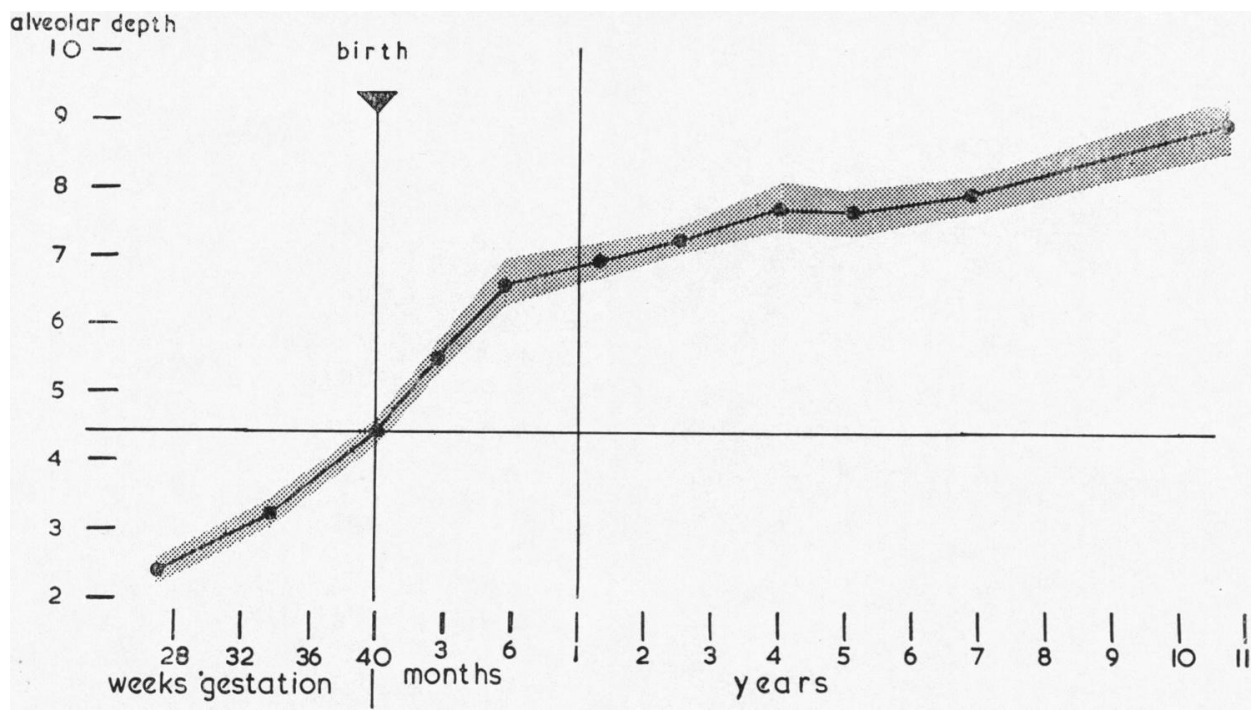

Frg. 2.-Graph showing the mean and standard error of mean of the radial alveolar counts ('alveolar depth'), related to age.

puberty. Unfortunately we were unable to continue our examination into the older age group, there being no suitable material available to us.

The counts given here represent the number of acini cut by an apparent random 'radius' within the terminal respiratory unit. The latter probably varies in form but basically is a compressed sphere. If this terminal unit were a sphere, the number of alveoli in it would be given by the formula $2 / 3 \mathrm{n}^{3}$, i.e. approximately $2 \cdot 1 \mathrm{n}^{3}$ (where ' $\mathrm{n}$ ' is the number of alveoli cut by the radius). If the terminal unit were a cube, ' $n$ ' would represent a half of the length of a side and the alveolar count $(2 n)^{3}$, i.e. $8 n^{3}$. The formula for a sphere represents the smallest theoretical number and that for the cube by no means the largest. If we take, for convenience, $4 n^{3}$, this gives the terminal respiratory unit at full term $4 \times(4.4)^{3}=340$ alveoli. At 1 year this becomes 1,370 , and at 10 years 2,900 , i.e. an apparent nine-fold increase.

\section{Discussion}

There is now no doubt that the ideas that the lungs are fully formed by 6 months' gestation, and that the act of breathing is responsible for later difference in appearance (Barnard and Day, 1937) or that the lung is mature at birth (Norris, Kockenderfer and Tyson, 1941), are false. We have found that the terminal respiratory unit contains apparently nine times as many alveoli at the age of 10 years as at birth. This does not represent the full rate of development as this assumes that the total number of terminal units remain the same. Willson (1928) showed that in white mice there was an increase in the number of branches of the respiratory tree from 21 and 23 in the newborn to 29 and 30 in the adult and, from the study of sections from lungs of 15 children, stated that the human lung tree showed a similar increase branching after birth. Bremer (1935) working on opossum lungs suggested that the bronchioles grew distally by muscularization and epithelialization of the alveolar ducts so that what were at one time alveolar ducts, later became respiratory bronchioles. This view was also held by Broman (1923). Animals apparently vary considerably in the degrees of relative lung maturity at birth (Broman, 1923; Engel, 1953), and thus animal studies are not directly applicable to man in this respect. It has been shown quite conclusively (Cohn, 1940) that in the rat, there is an active production of new alveoli in compensative hypertrophy of a lobe in response to the removal of another lobe of the same lung. Evidence regarding alveolar growth in man is very scanty and rests largely on finding mitotic figures in the lining cells of alveoli and respiratory tubules in infants. Palmer (1936) found 17 generations of respiratory tubes in the human newborn and Broman (1923) suggested that there were six to seven further generations found after birth. This gives 131,000 $\left(2^{17}\right)$ terminal respiratory units at birth and $2^{24}$, 
i.e. 1,677,000 in the mature lungs (a 127-fold increase in terminal units!). We have demonstrated that there is a nine-fold postnatal increase in the number of alveoli in the terminal unit. Thus there is a theoretical overall increase of $9 \times 127=11,243$, i.e. an increase of more than 10,000-fold after birth, which is much greater than that of the circulating blood cells. It is of interest that Willson (1928) considered that the air spaces in the young child were larger than in the adult, and suggested that children were normally in a state of relative emphysema. Dubreuil, Lacoste and Raymond (1936) considered that the lung of the newborn consisted of alveolar ducts only and that all of the alveoli developed after birth.

The method of alveolar multiplication is not certain. It has been suggested that the new alveoli are formed in utero by the production of septa across the existing saccula (Loosli and Potter, 1951). Ham and Baldwin (1941), who worked chiefly on pigs' lungs, looked upon the lung in Macklin's concept (1936), as being a structure in a state of functional interstitial emphysema, and they considered that new alveoli were not produced by the peripheral cells, but by the splitting of the alveolar walls and the penetration of air between the beds of capillaries in a kind of progressive, controlled interstitial emphysema. The now well established presence of a lining membrane to all alveoli, does not really invalidate their concept as a thin membrane could well be ballooned into the interstitial space. Fried (1956) from a study of rabbit lungs, considered that the interstitial cells of the alveolar septa, as well as becoming the intra-alveolar phagocytes, were also capable of forming alveolar walls themselves. Krahl (1955), following up the electron-micrographic studies of the lining membranes of the alveoli made by Low (1953), took the problem of development no further than Miller (1947) or Morison (1952) in showing that the epithelium of the peripheral alveoli was less attenuated than the most central ones.

The importance of the postnatal development of alveoli will be appreciated when we consider the possibility of factors such as air pollution or repeated respiratory infections interfering with alveolar proliferation and resulting in adults with a diminished reserve of alveoli.

\section{Summary}

A systematic and statistical study has been carried out on the lungs of children dying during the later part of gestation and through childhood up to 12 years of age.

An estimate has been made of the number of alveoli in the terminal respiratory unit and this shows a rapid increase during the first year after birth and a steady increase throughout childhood, there being apparently a nine-fold increase in the alveoli after birth.

If consideration is also given to the increased proliferation of the respiratory tree after birth, there is the possibility of a thousand-fold increase in the number of alveoli between birth and puberty.

REFERENCE;

Barnard, W. G. and Day, T. D. (1937). The development of the terminal air passages of the human lung. J. Path. Bact., 45, 67. Bremer, J. L. (1935). Postnatal development of alveoli in the mammalian lung in relation to the problem of the alveolar phagocyte. Contr. Embryol. Carneg. Instn, 25, 83.

Broman, I. (1923). Zur Kenntnis der Lungenentwicklung. Verh. anat. Ges. (Jena), 23, 83.

Cohn, R. (1940). The postnatal growth of the lung. J. thorac. Surg, 9, 274.

Dubreuil, G., Lacoste, A. and Raymond, R. (1936). Observations sur le développement du poumon humain. Bull. Histol. Appliq. Physiol., 13, 235.

Engel, S. (1953). The structure of the respiratory tissue in the newlyborn. Acta anat. (Basel), 19, 353.

Fried, B. M. (1956). The structure of the respiratory (terminal) portion of the lungs. A.M.A. Arch. intern. Med., 98, 691 .

Ham, A. W. and Baldwin, K. W. (1941). A histological study of the development of the lung with particular reference to the nature of alveoli. Anat. Rec., 81, 363.

Kölliker, A. (1881). (Cited by Engel, 1953.) Verh. phys.-med. Ges. Würzburg., 'Zur Kenntniss des Baues der Lunge des Menschen', 16, 1.

Krahl, V. E. (1955). Current concept of the finer structure of the lung. A.M.A. Arch. intern. Med., 96, 342.

Loosli, C. G. and Potter, E. L. (1951). The prenatal development of the human lung. Anat. Rec., 109, 320.

Low, F. N. (1953). The pulmonary alveolar epithelium of laboratory mammals and man. Ibid., 117, 241.

Macklin, C. C. (1936). Pulmonic alveolar epithelium-report of

a round-table conference. J. thorac. Surg., 6, 82.
Miller, W. S. (1947). The Lung. 2nd ed. Thomas, Springfield, Illinois.

Morison, J. E. (1952). Foetal and Neonatal Pathology, p. 134. Butterworth, London.

Norris, R. F., Kockenderfer, T. T. and Tyson, R. M. (1941). Development of the fetal lung with special reference to the lining of the alveoli and the effect of immaturity on respiration. Amer. J. Dis. Child., 61, 933.

Palmer, D. M. (1936). The lung of a human foetus of $170 \mathrm{~mm}$. Crown rump length. Amer. J. Anat., 58, 59 .

Willson, H. G. (1928). Postnatal development of the lung. Ibid., 41, 97 